Europe and no fans had been installed. I pointed out that many of the speakers had slides to show, and that there was no screen. Obligingly, somebody went out and came back with a sheet, a hammer, and some large nails, then launched an attack on the new woodwork. This gave a white surface and effectively destroyed the panelling.

Once when attending a medical meeting in Ghana I was invited to the annual dinner. I asked about after dinner speeches and was told that there would be only one (by the American ambassador). After he had sat down the toastmistress, resplendent in her red uniform, struck the table with her gavel and announced that I would be giving the next speech. At the time there were possible political implications about anything that was said, but one way out of such a dilemma is to take the name of the place or society letter by letter and speak about each in turn. Having been caught out completely I started to talk about Ghana, using this method to gain time. The letter G was easy: I could talk about the gratitude I felt for my invitation and the opportunity to see the country. When talking about this I was thinking about the next letter and realised at once that there was a problem: I was not $100 \%$ certain how to spell Ghana. I was $99 \%$ certain it was GHANA, but there was no room for error, and just suppose it was GAHNA; if I got it wrong there would be an international incident. As I talked about gratitude I was frantically looking around for a menu card to see if the word was there, but it was not, so I had to take a chance and went on bravely with $\mathrm{H}$ for hospitality before continuing with $\mathrm{A}$ for Accra, $\mathrm{N}$ for new friendships, and $\mathrm{A}$ for the American ambassador. Fortunately all was well, but it was an awkward moment.

I have known speakers to become tongue tied, but once had to treat a fairy queen who was unable to speak. She was in a pantomime at one of Edinburgh's main theatres in 1940 and had unfortunately yawned and dislocated her jaw just as the curtain went up. As the performance proceeded without a fairy queen I put her jaw back into place and she then quickly returned to the theatre. Between us, however, we must somehow have got the spells wrong because on the very day that I returned to Edinburgh from overseas service in 1946 the same theatre was burnt to the ground.

Edinburgh EH10 6DD

RONALD GIRDWOOD, MD, FRCP, emeritus professor of therapeutics

Correspondence to: 2 Hermitage Drive, Edinburgh EH10 6DD.

\title{
A psychiatrist in the fortune teller's tent
}

\author{
DILYS JONES
}

Yesterday afternoon, I found in my post a note from our ward sister, Anne. She was organising our annual secure unit summer fête and wanted to know whether I would be willing to participate again. Last year I was a fortune teller for the afternoon, sitting in a tent dressed in two tablecloths, a shawl, and a pair of pink floral curtains and adorned with large brass earrings.

The afternoon had been warm and I sat in the tent surrounded by draped shawls and potted plants. The crystal ball was an upturned sweet jar. The evening before had been spent reading a library book on palmistry. I looked forward to the afternoon.

The clients were a mixture and it seemed almost too easy to tell fortunes, So much could be gleaned from their physical appearance and general demeanour. The smiling cheerful pregnant lady who glowed wanted to know about her future children. I had seen the caring way in which her husband held her belongings and found a passage through the crowd for her. I did not think that I would be too inaccurate in predicting a long and happy life for her and her family. I had already decided to "predict" only happy events for people.

Young children came for their fortunes to be told (for a reduced fee of 5p). Predictions of tall dark husbands for the girls resulted in much giggling and smiling. The afternoon proceeded with a steady flow of clients. The relative ease with which people told me their secrets so unfalteringly was surprising and somewhat breathtaking. They did so more freely and willingly than many people seen for the first time in psychiatric outpatient departments.

\section{What about the poodle?}

One glamorous lady told how she had decided to leave her husband-he was standing not ten yards away outside the tentand run away with her lover. She wanted to know whether her poodle would miss her and how he would cope without her. She confided how violent her husband could be and how unhappy she had been. I tried to reassure her about the poodle as she could not take him with her. She tripped out, smiling, to take her husband's arm.

Only three men came to have their fortunes told, one of whom was a patient I knew from the unit. He was a large man with schizophrenia who demanded to know when he was going to leave hospital, get married, and have children. This was tricky as he clearly knew who I was and I had spoken to him only two days before on the subject of him leaving hospital. There had been no question of him doing so in the near future.

After studying his palm I answered as the fortune teller, saying that his discharge date was hazy but on the horizon. I read his marriage line as per the palmistry book, casting aside my doubts as a psychiatrist. He seemed satisfied and thanked me gravely, returning to the nurse who was waiting outside.

Shortly afterwards a lady in late middle age came in, dressed in crumpled grey. The remainder of her physical appearance was also crumpled grey. She was sad, anxious, and clearly had little money, if you could judge this by her appearance. She told me that she had come to the fête from a nearby village. She said that she was pleased to find a fortune teller as she had visited several before and had great faith in their powers. She looked so serious that I felt a momentary rise of panic - this was meant to be lighthearted fun and I. was in danger of being taken seriously. I compelled myself to stay as the fortune teller but found myself as psychiatrist. As her sad story unfolded I wondered whether she was suffering from depression. She described herself as a widow of four years with two grown up children, who were married and living in the north. Her close friend had died six months before. She had little to hold her here and her son wanted her to move north to live with him and his family. She said that she would find the break hard to make. She confided that she had had thoughts of ending her life after her friend had died, although she no longer felt like this. She then leaned forward and 
asked me if I could tell her whether she would move to her son's home and whether she would end her own life at some point in the future.

\section{Reading the right palm}

Playing for time, and trying to hide the concern I felt, I took her hand and studied her palm. I noticed her frown as I took her hand but did not ask why. I gently asked her questions, probing to establish whether she had any symptoms of depression. It seemed that she had been depressed but had recovered. She described visiting her general practitioner for help after her friend had died and when she had felt like ending her life. She told how he had wanted her to see a psychiatrist. "But I'd never go and see one of those-I don't need that." I felt guilty and fraudulent listening to her story. How was she to know that she was really talking to a psychiatrist? Having established that she had mild symptoms of anxiety only I urged her to talk further to her general practitioner about whether she should move to her son's home. I told her that should she ever feel as low as she did before she should seek help from her general practitioner. She agreed that this would be sensible, which gave me sufficient courage to revert to the role of fortune teller and tell her that the future did not hold suicide for her. She seemed content at this and smiled, and said that she had "got a lot off her chest." She thought that she would move to be with her son- "who had a room all ready for me."

As she left she looked at me knowingly and said-"You know, I've been to lots of fortune tellers and they always read the right palm. You read the left palm, didn't you?" She left smiling. I believe that she knew that she had been to see "one of those psychiatrists."

So this year I have told Anne that I will help with the fête again, but I am going to run a secondhand dress stall. Fortune telling is a little too much like practising psychiatry and on reflection the practice of psychiatry has much fortune telling in it.

\section{Eastleigh, Hants SO5 4RI}

DILYS JONES, BM, senior registrar in forensic psychiatry

Correspondence to: 49 Broomhill Way, Allbrook, Eastleigh, Hants SO5 4RL.

\section{JENNER'S HOUSE}

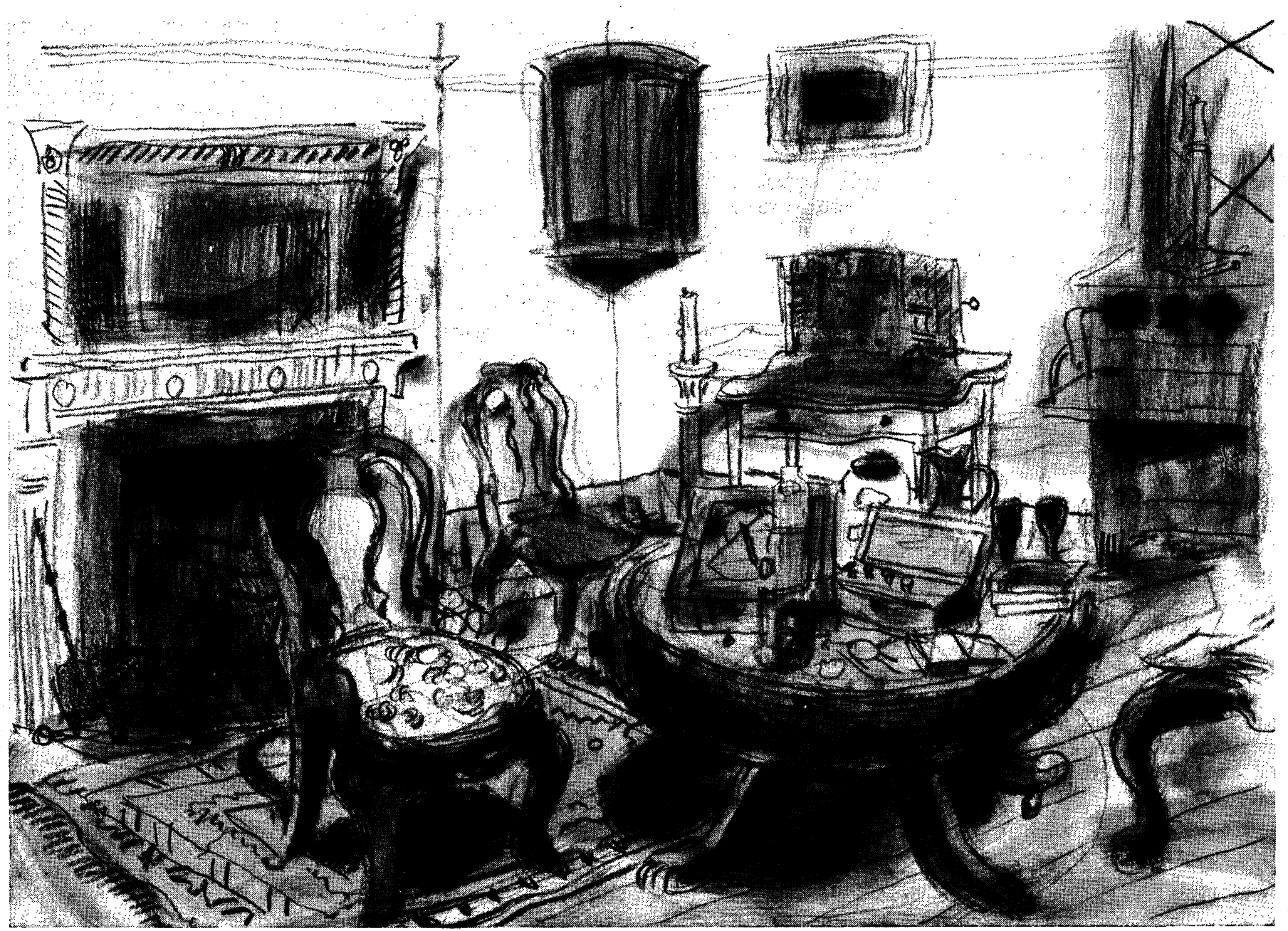

William Jenner's study, in the Chantry, Berkeley, Gloucestershire-which some of the BMA representatives at this year's ARM in Bristol visited (drawing by Jane Stanton). 